\title{
The Ancient State of Puyŏ in Northeast Asia: Archeology and Historical Memory. By Mark E. Byington. Cam- bridge and London: Harvard University East Asia Center, 2016. xv + 398 pp. [ISBN: 9780674737198]
}

Richard D. McBride II*

The early history of Northeast Asia, particularly the region conventionally referred to as "Manchuria," has a long and complex relationship with the polities, peoples, states, and cultures of the nation-states now commonly referred to as "Korea" and "China." The ancient history of Manchuria, and especially the cultural affiliation of the early states and polities that existed there in the remote past, has recently been a topic of energetic debate among East Asian politicians and scholars, particularly since the People's Republic of China launched the Northeast Project (Dongbei Gongcheng, 東北工程) in 2001 and the Republic of Korea responded by creating the Northeast Asia History Foundation (Tongbuga Yŏksa Chaedan, 東北亞歷史財團) in 2006. Mark Byington's monograph on the ancient state of Puyŏ is a careful and detailed study of the archeology and historiography of the early Manchurian state Puyŏ, which was traditionally claimed by Koguryŏ (trad., 37 BCE-668 CE) in its founding legend and Paekche (trad., 18 BCE-660 CE) as the surname of its ruling family, and thus by later Korean historians as one of the mainsprings of the ancient Korean people. This monograph, based on his 2003 Ph.D.

* Associate Professor and Chair of History, Brigham Young University-Hawaii, in Lā'ie, Hawai'i, USA 
dissertation, gets at the heart of the academic issues surrounding the Puyŏ people by examining the evidence, both archeological and historiographical, in a balanced, exacting, and critical manner.

The earliest certain mention of the Puyŏ (Ch. Fuyu) state in Chinese materials dates to the second century BCE, but, as Byington explains, it is clear from the context that Puyŏ had been established prior to that time. The Northeast Asian state centered on the Songhua river endured the ordinary vicissitudes incumbent upon all tribal polities in early Manchurian history because of the highly competitive nature of tribal society in the region. Nevertheless, Puyŏ enjoyed generally peaceful relations with the various early states in the Chinese realm, due in large part to its geographic distance from and tributary relationship with the more centralized states of the Central Plain. Puyŏ was eventually destroyed in 346 CE, a victim of the rise of the Murong Xianbei.

The book comprises an introduction, seven chapters, a conclusion, and three appendices on the historical geography of Puyŏ, as well as a bibliography and index. In addition, 37 instructive color plates are found between chapter 5 and 6 (after p. 180). The introduction (pp. 1-7) and chapter 1, "The Beginnings of History in Northeast Asia" (pp. 8-24) lay out Byington's approach to the material covered in the book. Because of all the political rhetoric and hype surrounding the conflicting claims surrounding the ethnic identity of Puyŏ, Byington sees it as "an opportunity and an obligation" (p. 4) to engage in a complete reassessment of KoreaManchuria history on its own terms by testing and challenging the established paradigms, which are often dependent on literary documents, through use of recently excavated archeological material. Chapter 1 briefly lays out the place of Puyŏ in history and historiography, the thorny position of Puyŏ in modern scholarship, and the deployment of Puyŏ in ethnicity studies and new religions in Korea in the late $19^{\text {th }}$ and early $20^{\text {th }}$ centuries. This prefaces his articulation of approaching the history of Puyŏ from "a new perspective" that "differentiates between Puyŏ as a state in its own right and Puyŏ as a historiographical device from which later states drew their political legitimacy" (p. 22). 
The balance of the book is constructed in a calculating manner that establishes context and then, with exacting detail and evidence, lays out Byington's balanced approach to the material. Chapter 2, "Ancient Peoples and States of Northeast China and Korea" (pp. 24-61) describes the growth of the northeastern Chinese state of Yan into southern Manchuria in the fourth century BCE and its relationship with the people or polity of Chosonn as well as the spread of iron technology as a result of the Yan expansion. The Puyŏ polity formed during this period to the northeast. Chapters 3 and 4 treat the archeology of Puyŏ in detail. Chapter 3, subtitled, "Bronze Age Antecedents" (pp. 62-100) introduces the various cultures present in Manchuria during the Bronze Age and makes a case for the Xituanshan society occupying the vicinity of the Songhua river in the second millennium BCE to the third century BCE as the culture that eventually developed into the Puyŏ polity. Chapter 4, subtitled "Formation of the Puyŏ State" (pp. 101-139), makes a case for the culture of the early Puyŏ state and identities probable archeological sites where the Puyŏ people lived and were buried, noting the introduction and spread of iron technology and trade with the Han Chinese during the Western Han period (ca. 206 BCE-24 CE).

Chapter 5, "History of the Puyŏ State" (pp. 140-180) pieces together the textual materials dealing with Puyŏ that were written by neighboring and often adversarial peoples, the contemporary states of the Chinese Central Plains and Koguryŏ to the south. The extant historiographical materials can tell us something of Puyŏ's position in Han-dynasty frontier diplomacy during the Western Han, the formalized relationship that existed later during the Eastern Han period (particularly 49-189 CE), and its relations with the Gongsun house that controlled Liaodong in the late second and early third centuries (189-238 CE) and the Jin dynasty prior to the destruction of the state by the Murong (265-346). Byington then explains the position of Puyŏ in Koguryŏ history, the importance of Puyŏ in the Koguryŏ founding myth, and articulates how Koguryŏ laid claim to Puyŏ's heritage as a means of asserting political legitimacy.

Chapter 6, "Society and Territory of the Puyŏ State" (pp. 181-230) 
compares the Puyŏ people depicted in literary materials to the archeological record of their society and culture. Byington explains Puyŏ social customs and organization from an archeological perspective, which sheds light on the snippets of information available in the historiographical materials. His interpretation of the archeological materials suggests, for example, that Puyŏ was authoritarian and highly stratified, that its people possessed a keen sense of morality and followed social etiquette that even the discerning Chinese states of Han and Wei admired. The chapter also contains a study of Puyŏ's defensive network of forts and strongholds, which enables Byington to ascertain the extent of Puyŏ's boundaries. The evidence suggests that, beyond its political center in present-day Dongtuanshan in Jilin, Puyŏ territory ranged throughout central Jilin prefecture, including parts of northeast Liaoning (p. 229).

Chapter 7, "Post-Conquest Puyŏ Survivals" (pp. 231-278) analyzes what happened to remnant Puyŏ peoples after their destruction at the hands of Murong Xianbei in 346. Some Puyŏ elites fled south to the Central Plains, and after Koguryŏ occupied the Puyŏ heartland in the years in the mid-fourth century following the fall of the state, some refugees made an exodus to the north, becoming the Damolou. The chapter deals primarily with the importance of Puyŏ in Koguryŏ and Paekche history. In this context, Byington explains the relationship between the names "Eastern Puyŏ," "Northern Puyŏ," and "Puyŏ" that appear in the legends concerning the Koguryo founder Chumong. He argues persuasively that the best explanation is to understand the different qualifications to Puyŏ to refer to various strata in the evolving story of the Koguryo founder. This chapter also explains how the name Puyŏ continued to carry cachet in Northeast Asia, and how Koguryŏ and the Mohe (Malgal in Korean) struggled for control over this territory. Eventually, "Puyŏ Superior Prefecture" (Puyŏbu) was established by the Parhae state (698-926) in the old core region of Puyŏ. Byington then critically assesses the evidence regarding Paekche as a Puyŏ successor state and the alleged Puyŏ origins of the Paekche royal family.

Byington's conclusion (pp. 279-306) is dynamic inasmuch as it does 
not merely summarize all that has gone before, but it is also constructed to assert a two-phase approach to state formation in Puyŏ: (1) social and (2) political. More important, while recognizing the inherent limits of archeological interpretation, he argues that secondary state formation was accomplished because of the incursions of the Chinese Yan and Han states. Byington also marshals evidence to challenge the conventionallyaccepted views that assert that the migration legends of early states in the Korea-Manchuria area reflect actual, historical migrations and the imposition of foreign rule. Instead, Byington holds the position that the creators of these stories had other goals in mind, such as a desire to draw upon the prestige of the vanquished Puyŏ state to create greater parity among the early state in Northeast Asia.

The Ancient State of Puyo in Northeast Asia will become one of the seminal texts for students of early Korean and Manchurian history. Its conscious and careful blending of historiographical and archeological material and theory should serve as a model for future students and scholars who would tackle the complex yet fascinating history of this still-notwell-understood region of the world. Although the subject material is in no sense easy to understand, Byington's ability to articulate scholarly theory and apply it to the early history of Korea-Manchuria demonstrate his exceptional skill as a scholar. In conclusion, although Byington's book will not settle the current political debates regarding Puyŏ and other early states in Northeast Asia, he indisputably establishes that wrangling over the cultural cachet of Puyŏ for legitimacy has much deeper roots than conventionally accepted. 
